\title{
Experimental study on microwave torrefaction of lignocellulosic biomass
}

\author{
Monika Kosowska-Golachowska ${ }^{1, *}$, Aneta Magdziarz ${ }^{2}$, Paweł Janus ${ }^{1}$, Dariusz Urbaniak ${ }^{1}$ \\ ${ }^{1}$ Czestochowa University of Technology, Institute of Thermal Machinery, Armii Krajowej 21, \\ Czestochowa, Poland \\ ${ }^{2}$ AGH University of Science and Technology, Mickiewicza 30 Av., 30-056 Krakow, Poland
}

\begin{abstract}
This paper presents preliminary research of lignocellulosic biomass torrefaction by using microwave heating. The experimental setup was developed using a microwave oven with $2.45 \mathrm{GHz}$ frequency. The torrefaction effect was studied by varying the microwave power level (160$480 \mathrm{~W}$ ) and reaction time (5-30 min). The two Polish biomass feedstock, agricultural residue (wheat straw) and energy crop (Miscanthus giganteus) were used in this study. Fuel properties like $\mathrm{H} / \mathrm{C}$ and $\mathrm{O} / \mathrm{C}$ ratio were assessed from elemental composition. Mass yield and energy yield of the torrefied fuels were also determined. It was found that higher microwave power levels contributed to higher heating rate and reaction temperature, and thus produced the torrefied biomass with higher heating value and lower $\mathrm{H} / \mathrm{C}$ and $\mathrm{O} / \mathrm{C}$ ratios.
\end{abstract}

\section{Introduction}

Lignocellulosic biomass, such as wood, crops and agricultural residues is one of the most promising, renewable alternative for fossil fuels [1-3]. Biomass is considered to be a carbon-neutral fuel in many countries. Besides biomass contains more volatiles and a lower carbon content than coal does, which makes biomass a highly reactive fuel. Raw biomass has several disadvantages compared with fossil fuels, including high moisture content, relatively low calorific value, low energy density, poor grindability, large volume of area required for storage, economic problems associated with transportation and distribution. Several of these disadvantages are attributed to the low bulk density of biomass, especially for agricultural residues [2]. There are many thermo-chemical conversion technologies of biomass, including torrefaction, carbonization, pyrolysis and gasification. Torrefaction is suggested to be an effective pretreatment method to reduce the cost of biomass provision and improve the fuel properties [4]. Torrefaction of biomass is a mild pyrolysis technology in which biomass is thermally pretreated at $200-300{ }^{\circ} \mathrm{C}$ in an inert and atmospheric pressure environment [1, 3-13]. Cellulose, hemicellulose, and lignin in lignocellulosic biomass, as well as carbohydrate, protein, and lipid in algal biomass are decomposed after torrefaction. The produced solid has better fuel quality because of its higher calorific value, lower atomic $\mathrm{H} / \mathrm{C}$ and $\mathrm{O} / \mathrm{C}$ ratios, better grindability, and improved

\footnotetext{
* Corresponding author: kosowska@imc.pcz.czest.pl
} 
hydrophobicity. Torrefaction can also lower the transportation and storage cost of various biomass wastes undergoing densification [3]. Torrefied biomass is successfully applied as a biofuel for combustion, co-combustion or gasification processes.

In recent years, there have been several studies on the torrefaction of biomass. Most of them used conventional heating method and the effects of process temperature and process time on torrefaction of biomass were discussed. Microwave irradiation provides an alternative method which has a lot of advantages, such as fast internal heating, volumetric heating, and low energy consumption. Therefore, it is widely used in many aplications including drying, digestion and pyrolysis. Microwave torrefaction of some biomass like wheat and barley straw [7], rice straw and pennisetum [6], rice husk and sugarcane residues [11] have been reported in the last few years.

The objectives of this study was to investigate the impact of microwave power and reaction time on the properties of what straw and Miscanthus giganteus by microwaveinduced torrefaction.

\section{Materials and methods}

\subsection{Biomass tested}

The two Polish lignocellulosic biomass feedstock, agricultural residue (wheat straw) and energy crop (Miscanthus giganteus) were used in this study. Table 1 shows the proximate and ultimate analyses of the tested biomass. The compositions of both biomass samples are similar but the Miscanthus giganteus seems to have slightly better properties than the wheat straw.

Table 1. Proximate and ultimate analyses of the tested biomass.

\begin{tabular}{|l|c|c|}
\hline \multicolumn{2}{|l|}{ Wheat straw } & Miscanthus giganteus \\
\hline Proximate analysis (dry basis) & 8.4 & 6.0 \\
\hline Moisture, wt \% & 69.1 & 75.8 \\
\hline Volatiles, wt \% & 7.4 & 2.8 \\
\hline Ash, wt \% & 15.1 & 15.4 \\
\hline Fixed carbon, wt \% & 17.84 & 18.79 \\
\hline Higher heating value, MJ/kg & & 47.3 \\
\hline Ultimate analysis (dry basis) & 44.75 & 6.24 \\
\hline Carbon, wt \% & 6.63 & 0.2 \\
\hline Hydrogen, wt \% & 0.83 & 0.03 \\
\hline Nitrogen, wt \% & 0.08 & 46.23 \\
\hline Sulphur, wt \% & 47.71 & \\
\hline Oxygen (by difference), wt \% & & \\
\hline
\end{tabular}




\subsection{Torrefaction experimental apparatus and procedure}

The schematic diagram of the microwave torrefaction set-up is shown in Figure 1. The experimental apparatus was developed using a microwave oven with $2.45 \mathrm{GHz}$ frequency. The microwave power can be varied from 0 to $800 \mathrm{~W}$ through a power controller located at the front panel. A custom-made cylindrical quartz glass reactor (Fig. 2), $120 \mathrm{~mm}$ in length and $30 \mathrm{~mm}$ in diameter was used in this study. The reactor has three ports, first for nitrogen purging, second for K-type thermocouple and third for exhaust gases. The thermocouple was covered with a quartz glass tube throughout the microwave cavity and only exposing the tip inside the biomass sample. The temperature data was recorded continuously on a laptop computer using the Advantech USB data acquisition device. Nitrogen gas was continuously purged through one of the ports of the reactor at a constant rate of $50 \mathrm{ml} / \mathrm{min}$ using a flow meter. Approximately $4 \pm 0.02 \mathrm{~g}$ biomass was placed in the reactor for each experiment. The particle size of the tested biomass was 0.1-0.2 mm.

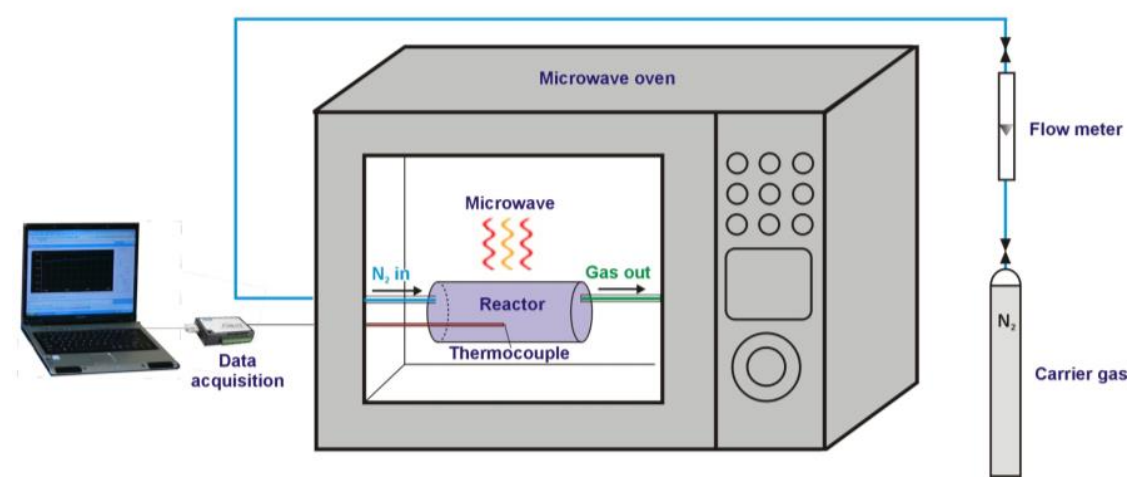

Fig. 1. Schematic diagram of the experimental apparatus for microwave torrefaction.

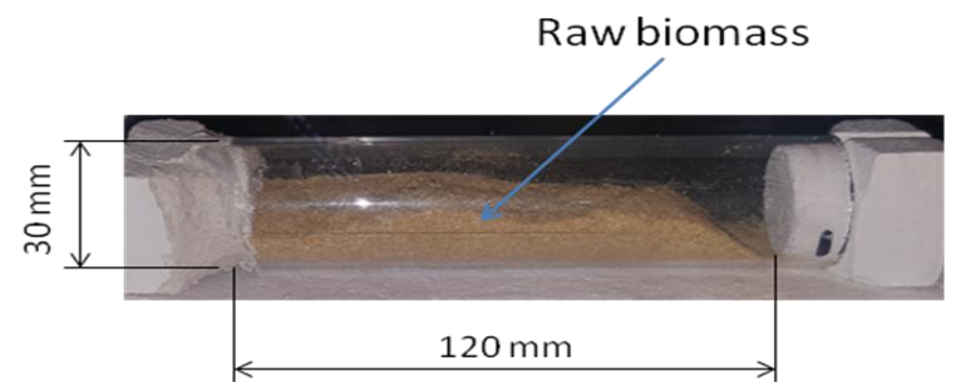

Fig. 2. The torrefaction reactor.

In this study, two experimental parameters, including microwave power level and processing time were varied. The details of the operating conditions are depicted in Table 2.

Table 2. Operating conditions for microwave torrefaction.

\begin{tabular}{|l|c|}
\hline Process parameters & Conditions \\
\hline Microwave power, W & 160,320 and 480 \\
\hline Processing time, min & $5,10,15,20$ and 30 \\
\hline
\end{tabular}




\subsection{Analytical methods}

After each experiment the torrefied biomass was mixed gently before drawing samples for further analysis. The ultimate analysis (carbon, hydrogen and nitrogen content) of torrefied biomass was measured by Elemental Analyzer Truespec CHN Leco. The higher heating values (HHV) of the torrefied samples were calculated using the following expression, as derived by Friedl et al. [14].

$$
\mathrm{HHV}=3.55 \times \mathrm{C}^{2}-232 \times \mathrm{C}-2230 \times \mathrm{H}+51.2 \times \mathrm{C} \times \mathrm{H}+131 \times \mathrm{N}+20600
$$

\subsection{Mass and energy yield}

The energy yield of torrefied biomass is considered as a useful assessment of the process $[1,3-11]$. The mass yield $\left(\eta_{m}\right)$, energy density ratio (ER) and energy yield $\left(\eta_{e}\right)$ were calculated by using the following equations:

$$
\begin{gathered}
\eta_{m}=\left(m_{t} / m_{r}\right) \times 100 \\
\mathrm{ER}=\left(\mathrm{HHV}_{t} / \mathrm{HHV}_{r}\right) \\
\eta_{e}=\eta_{m} \times \mathrm{ER}
\end{gathered}
$$

where $m_{t}$ and $m_{r}$ are the mass of the torrefied and raw biomass in dry basis, respectively. $\mathrm{The} \mathrm{HHV}_{\mathrm{t}}$ and $\mathrm{HHV}_{\mathrm{r}}$ are the higher heating values of the torrefied and raw biomass.

\section{Results and discussion}

\subsection{Temperature profiles}

Reaction temperature is one of the most important parameters affecting thermal treatments [6]. Figure 2 shows the temperature profiles of microwave torrefaction of wheat straw and Miscanthus giganteus at the microwave power level of 160,320 and $480 \mathrm{~W}$. Initially, torrefaction was tested at a power level of $160 \mathrm{~W}$. The temperature increased rapidly in the first $13-15 \mathrm{~min}$, reached $200{ }^{\circ} \mathrm{C}$ in $10 \mathrm{~min}$ for Miscanthus giganteus and 12 min for wheat straw and maintained above $220^{\circ} \mathrm{C}$. The maximum heating rate was approximately $50{ }^{\circ} \mathrm{C} / \mathrm{min}$ for wheat straw and Miscanthus giganteus while the average heating rate was $20{ }^{\circ} \mathrm{C} / \mathrm{min}$ for wheat straw and $25{ }^{\circ} \mathrm{C} / \mathrm{min}$ for Miscanthus giganteus. When the microwave power level increased from 160 to $320 \mathrm{~W}$, the final temperature in the first 5 min increased from 85 to $195^{\circ} \mathrm{C}$ for wheat straw. Similarly, the final temperature in the first 5 min increased from 105 to $220{ }^{\circ} \mathrm{C}$ for Miscanthus giganteus. Satpathy 2014 et al. [7] reported that the initial higher heating rates may be attributed to the availability of moisture in the initial phase, which is a good absorber of microwave radiation.

Generally, the final temperature and heating rate of Miscanthus giganteus were slightly higher than those of wheat straw. Therefore, this may imply that Miscanthus giganteus can absorb more microwave irradiation than wheat straw, which means Miscanthus giganteus has better dielectric properties. The temperature at $480 \mathrm{~W}$ increased rapidly to $380{ }^{\circ} \mathrm{C}$ for wheat straw and $390{ }^{\circ} \mathrm{C}$ for Miscanthus giganteus in about $7 \mathrm{~min}$ with the maximum heating rate between 90 and $95{ }^{\circ} \mathrm{C} / \mathrm{min}$. The final temperature and heating rate at the microwave power level of $480 \mathrm{~W}$ were too high for torrefaction process requirement. 
a) Wheat straw

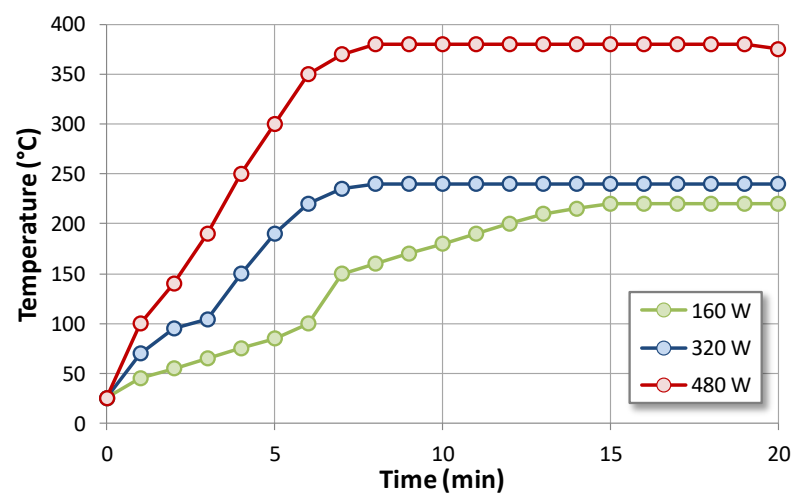

b) Miscanthus giganteus

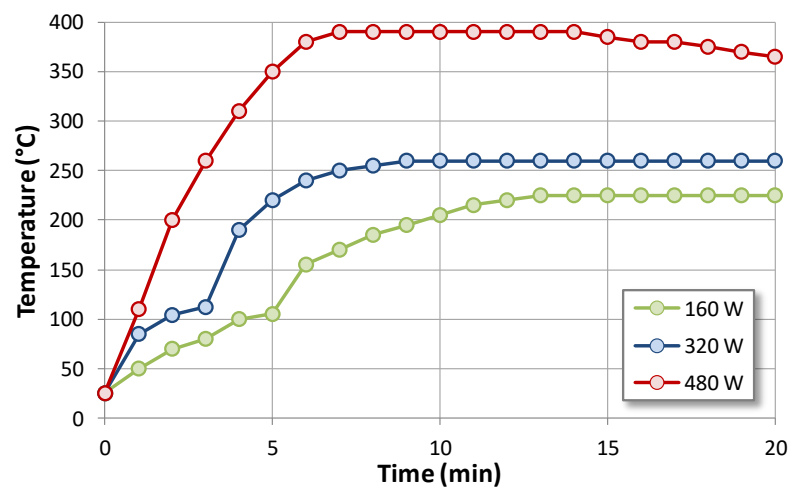

Figure 3. Temperature profiles of wheat straw (a) and Miscanthus giganteus (b) at different microwave power.

According to the results, 160 and $320 \mathrm{~W}$ microwave power levels were suitable for the torrefaction of the tested biomass. Further experiments were conducted at two microwave power levels: 160 and $320 \mathrm{~W}$ and five processing times: 5, 10, 15, 20 and $30 \mathrm{~min}$.

\subsection{Composition of torrefied biomass}

The elemental composition of torrefied wheat straw and Miscanthus giganteus is presented in Table 3. It can be seen that microwave power and processing time significantly affected the $\mathrm{C}, \mathrm{H}$ and $\mathrm{O}$ content of the torrefied biomass. The carbon content increased, whereas the hydrogen and oxygen content decreased with increasing power and reaction time. After torrefaction at $320 \mathrm{~W}$ microwave power level for 30 min processing time the $\mathrm{C}$ content increased by $14,4 \%$ and $16,7 \%$ in wheat straw and Miscanthus giganteus, respectively. This also shows that Miscanthus giganteus tended to carbonize more under microwave irradiation. The atomic $\mathrm{H} / \mathrm{C}$ and $\mathrm{O} / \mathrm{C}$ ratios of raw wheat straw were 0.15 and 1.06 and those of raw Miscanthus giganteus were 0.13 and 0.98 , respectively. Both $\mathrm{H} / \mathrm{C}$ and $\mathrm{O} / \mathrm{C}$ ratios decreased with increase in microwave power level and processing time. The atomic $\mathrm{H} / \mathrm{C}$ and $\mathrm{O} / \mathrm{C}$ ratios of torrefied wheat straw were 0.10 and 0.78 , and those of torrefied Miscanthus giganteus were 0.07 and 0.67 , respectively when torrefied at $320 \mathrm{~W}$ for $30 \mathrm{~min}$. Therefore, microwave torrefaction should be capable of being considered as an efficient and effective method to reduce $\mathrm{O} / \mathrm{C}$ ratio. 
Table 3. Ultimate analysis of torrefied wheat straw and Miscanthus giganteus.

\begin{tabular}{|c|c|c|c|c|c|c|c|}
\hline $\begin{array}{c}\text { Power } \\
\text { (W) }\end{array}$ & $\begin{array}{l}\text { Time } \\
(\mathrm{min})\end{array}$ & $\mathrm{C}$ & $\mathrm{H}$ & $\mathrm{N}$ & $\mathrm{O}^{\mathrm{a}}$ & $\mathrm{H} / \mathrm{C}$ & $\mathrm{O} / \mathrm{C}$ \\
\hline \multicolumn{8}{|c|}{ Wheat straw } \\
\hline \multicolumn{2}{|c|}{ untreated } & 44.75 & 6.63 & 0.83 & 47.79 & 0.15 & 1.06 \\
\hline \multirow{5}{*}{160} & 5 & 45.06 & 6.56 & 0.81 & 47.57 & 0.15 & 1.05 \\
\hline & 10 & 45.93 & 6.42 & 0.75 & 46.90 & 0.14 & 1.02 \\
\hline & 15 & 47.35 & 6.33 & 0.73 & 45.59 & 0.13 & 0.96 \\
\hline & 20 & 48.62 & 6.21 & 0.69 & 44.48 & 0.12 & 0.91 \\
\hline & 30 & 50.58 & 5.97 & 0.64 & 42.81 & 0.11 & 0.85 \\
\hline \multirow{5}{*}{320} & 5 & 47.96 & 6.48 & 0.87 & 44.69 & 0.14 & 0.93 \\
\hline & 10 & 49.44 & 6.36 & 0.91 & 43.29 & 0.13 & 0.88 \\
\hline & 15 & 50.61 & 6.22 & 0.93 & 42.24 & 0.12 & 0.83 \\
\hline & 20 & 51.27 & 6.08 & 0.93 & 41.72 & 0.11 & 0.81 \\
\hline & 30 & 52.31 & 5.73 & 0.95 & 41.01 & 0.10 & 0.78 \\
\hline \multicolumn{8}{|c|}{ Miscanthus giganteus } \\
\hline \multicolumn{2}{|c|}{ untreated } & 47.3 & 6.24 & 0.2 & 46.26 & 0.13 & 0.98 \\
\hline \multirow{5}{*}{160} & 5 & 48.01 & 5.92 & 0.21 & 45.86 & 0.12 & 0.96 \\
\hline & 10 & 49.24 & 5.89 & 0.36 & 44.69 & 0.11 & 0.91 \\
\hline & 15 & 51.03 & 5.44 & 0.39 & 43.13 & 0.10 & 0.85 \\
\hline & 20 & 53.08 & 5.13 & 0.41 & 41.38 & 0.10 & 0.78 \\
\hline & 30 & 54.64 & 5.05 & 0.46 & 39.85 & 0.09 & 0.73 \\
\hline \multirow{5}{*}{320} & 5 & 50.96 & 5.47 & 0.30 & 43.27 & 0.11 & 0.85 \\
\hline & 10 & 53.79 & 5.21 & 0.35 & 40.65 & 0.10 & 0.76 \\
\hline & 15 & 54.93 & 5.08 & 0.42 & 39.57 & 0.09 & 0.72 \\
\hline & 20 & 55.51 & 4.98 & 0.44 & 39.07 & 0.08 & 0.70 \\
\hline & 30 & 56.75 & 4.52 & 0.49 & 38.24 & 0.07 & 0.67 \\
\hline
\end{tabular}

${ }^{\mathrm{a}}$ calculated by difference

\subsection{Heating value of torrefied biomass}

The higher heating values of wheat straw and Miscanthus giganteus for different processing time at the microwave power levels of 160 and $320 \mathrm{~W}$ are shown in Figure 4. 
The average HHV's of raw wheat straw and Miscanthus giganteus were 17.84 and 18.79 $\mathrm{MJ} / \mathrm{kg}$, respectively. The highest HHV's of torrefied biomass were $20.81 \mathrm{MJ} / \mathrm{kg}$ for wheat straw and $21.98 \mathrm{MJ} / \mathrm{kg}$ for Miscanthus giganteus for the processing time of $30 \mathrm{~min}$ at the microwave power level of $320 \mathrm{~W}$. Generally, higher microwave power level and processing time contributed to higher heating value of torrefied biomass. The trends are consistent with those found in the literature [5-7] but the increase of HHV's in this study are lower as compared to the increase of HHV values of rice straw and Pennisetum (30\% and $56 \%$, respectively) after torrefaction at $300 \mathrm{~W}$ and $25 \mathrm{~min}$ [6]. Similar HHV values for torrefied wheat straw were reported by Satpathy [7].

a) $160 \mathrm{~W}$

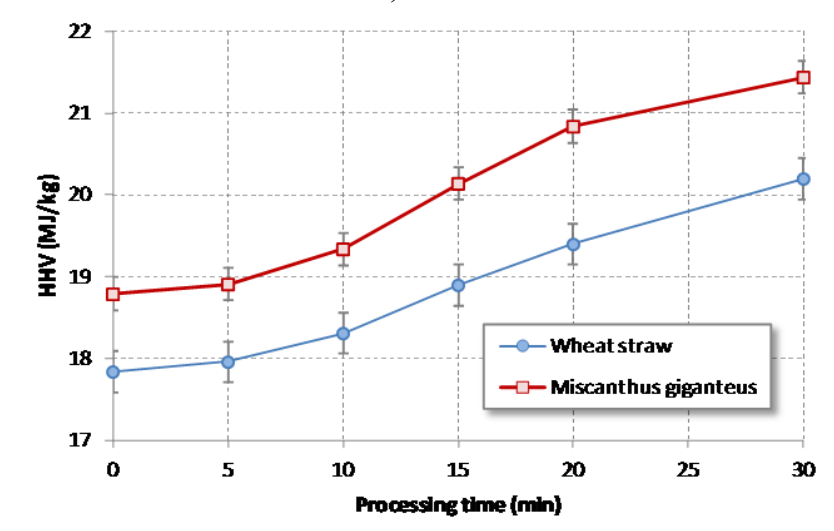

b) $320 \mathrm{~W}$

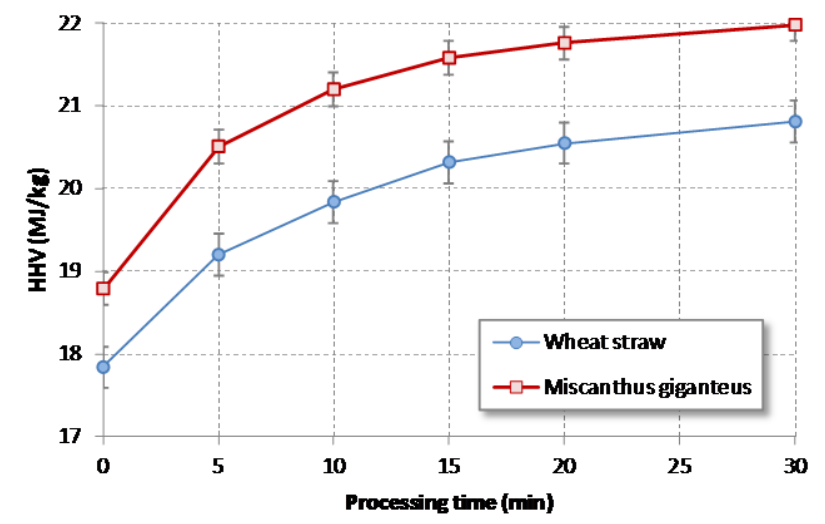

Figure 4. Higher heating values of torrefied biomass at $160 \mathrm{~W}$ (a) and $320 \mathrm{~W}$ (b) microwave power levels for different processing time.

\subsection{Mass and energy yield}

Mass and energy yield of torrefied biomass decreased with increase in microwave power and reaction time. After torrefaction at $320 \mathrm{~W}$ microwave power level for $30 \mathrm{~min}$ processing time the energy density increased by $14,3 \%$ in wheat straw with corresponding mass yield of $71 \%$ and energy yield of $82 \%$. For Miscanthus giganteus, energy density was found to increase by $14,5 \%$ with reduced mass yield of $65 \%$ and higher energy yield of $76 \%$. Mass and energy balance after microwave torrefaction is shown in Figure 5. After the microwave torrefaction at $320 \mathrm{~W}$ microwave power level for 30 min processing time, 1 mass unit and 1 energy unit of raw wheat straw was converted into 0.71 mass unit and 0.82 
energy unit of solid. Besides 1 mass unit and 1 energy unit of raw Miscanthus giganteus was converted into 0.65 mass unit and 0.76 energy unit of solid.
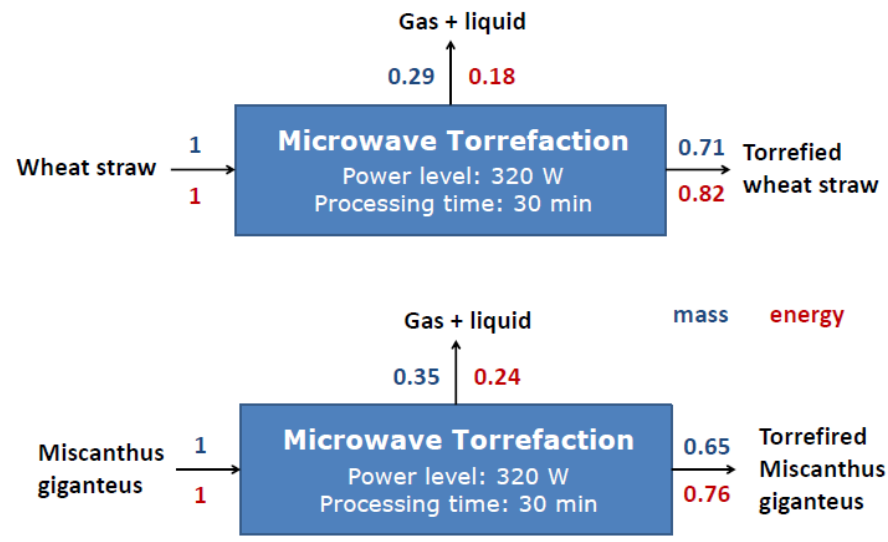

Figure 5. Mass and energy balance of microwave torrefaction of wheat straw (a) and Miscanthus giganteus (b).

\section{Conclusions}

Microwave power level and processing time were the major parameters affecting the performance of microwave torrefaction. Power level is suggested to be $320 \mathrm{~W}$ and torrefaction should be carried out for 20-30 $\mathrm{min}$. Microwave-induced torrefaction significantly improved the fuel characteristics like $\mathrm{O} / \mathrm{C}, \mathrm{H} / \mathrm{C}, \mathrm{HHV}$, energy density of the tested biomass. From the results of this study microwave irradiation can effectively be used for torrefaction of wheat straw and Miscanthus giganteus.

\section{References}

1. M. Wilk, A. Magdziarz, Energy 140, 1292-1304 (2017)

2. M. Kosowska-Golachowska, H. Otwinowski, K. Wolski, A. Kijo-Kleczkowska, T. Musiał, K. Środa, D. Richter, Renewable Energy Sources: Engineering, Technology, Innovation (Springer Proceedings in Energy, 2018)

3. S.H. Ho, C. Zhang, W.H. Chen, Y. Shen, J.S. Chang, Biores. Techn. 264, 7-16 (2018)

4. M. Kwapinska, G. Xue, A. Horvat, L. P. L. M. Rabou, S. Dooley, W. Kwapinski, J. J. Leahy, Energy\&Fuels 29, 7290-7300 (2015)

5. X. Wang, H. Chen, K. Luo, J. Shao, H. Yang, Energy\&Fuels 22, 67-74 (2008)

6. Y.F. Huang, W.R. Chen, P.T. Chiueh, W.H. Kuan, S.L. Lo, Biores. Techn. 123, 1-7 (2012)

7. S.K. Satpathy, L.G. Tabil, V. Meda, S.N. Naik, R. Prasad, Fuel 124, 269-278 (2014)

8. D. Beneroso, J.M. Bermúdez, M.A. Montes-Morán, A. Arenillas, J.A. Menéndez, Biores. Techn. 144, 240-246 (2013)

9. D. Beneroso, J.M. Bermúdez, A. Arenillas, J.A. Menéndez, Biores. Techn. 218, 687691 (2016)

10. Qinglong Xie et al., Biores. Techn. 156, 291-296 (2014)

11. M.J. Wang, Y.F, Huang, P.T. Chiueh, W.H. Kuan, S.L. Lo, Energy 37, 177-184 (2012)

12. M. Amer, et al., Biores. Techn. 286, 121400, (2019)

13. T. Botelho, M. Costa, M. Wilk, A. Magdziarz, Fuel 212, 95-100 (2018)

14. A. Friedl, E. Padouvas, H. Rotter, K. Varmuza Anal Chim Acta 544, 191-198 (2005) 